\title{
Differential Effects of Renin-Angiotensin System Blockade on Atherogenesis in Cholesterol-fed Rabbits
}

\author{
Joseph R. Schuh, Delores J. Blehm, Gregory E. Frierdich, Ellen G. McMahon, and Edward H. Blaine \\ Department of Cardiovascular Diseases Research, G. D. Searle \& Co., St. Louis, Missouri 63167
}

\begin{abstract}
To investigate the mechanism by which angiotensin-converting enzyme (ACE) inhibition attenuates atherogenesis, we have studied the effects of a nonsulf hydryl ACE inhibitor, enalapril, and an angiotensin receptor antagonist, SC-51316, in cholesterol-fed rabbits. After 3 mo of enalapril treatment $(10 \mathrm{mg} / \mathrm{kg}$ per d, p.o.) the percent plaque areas in the thoracic aortas of treated animals were significantly reduced (controls: 86.8 $\pm 3.5 \%$; treated: $31.1 \pm 8 \%, P<0.001$ ). Aortic cholesterol content was also reduced (controls: $31.4 \pm 3.2 \mathrm{mg} / \mathrm{g}$ tissue; treated: $7.4 \pm 1.8 \mathrm{mg} / \mathrm{g}, P<0.001$ ). Enalapril had no signifcant effect on plasma lipid levels or conscious blood pressure. In a second study, the angiotensin II receptor antagonist SC51316 was administered at a dose equivalent to enalapril at blocking angiotensin pressor effects in vivo $(30 \mathrm{mg} / \mathrm{kg}$ per d, p.o.). Evaluation after 3 mo indicated no significant attenuation of aortic atherosclerosis. These results demonstrate that: $(a)$ enalapril attenuates atherogenesis without affecting either blood pressure or plasma lipid levels; $(b)$ antioxidant activity, found with sulfhydryl-containing ACE inhibitors, is not necessary for reducing plaque formation; and $(c)$ the attenuation of atherogenesis by ACE inhibition may not be due to blockade of the renin-angiotensin system. Alternatively, one must consider the multiple effects of ACE inhibition on other hormone systems, such as bradykinin, or the possibility that alternate angiotensin II receptors may be involved in atherosclerosis. ( $J$. Clin. Invest. 1993. 91:1453-1458.) Key words: enalapril • SC-51316 - converting enzyme inhibitors • receptor antagonists • blood pressure
\end{abstract}

\section{Introduction}

The importance of high blood pressure as a risk factor for developing cardiovascular disease is well established. However, it has been found that drug therapies that successfully reduce blood pressure and the incidence of stroke do not necessarily reduce the morbidity and mortality associated with coronary artery disease $(1,2)$. These findings appear to indicate a multifactorial relationship between hypertension and atherosclerosis, suggesting that additional mechanisms, other than in-

Address correspondence to Dr. Joseph R. Schuh, G. D. Searle \& Co., $800 \mathrm{~N}$. Lindbergh Boulevard, St. Louis, MO 63167. Edward H. Blaine's current address is John M. Dalton Research Center, University of Missouri, Columbia, MO 65211.

Received for publication 24 July 1992 and in revised form $25 \mathrm{No}$ vember 1992

J. Clin. Invest.

(C) The American Society for Clinical Investigation, Inc.

$0021-9738 / 93 / 04 / 1453 / 06 \quad \$ 2.00$

Volume 91, April 1993, 1453-1458 creased systemic blood pressure, contribute to the accelerated atherosclerosis associated with hypertension. Increased plasma or tissue levels of vasoactive hormones, such as angiotensin II, may play a role in such mechanisms (3). This possibility is further supported by a report showing that, independent of other risk factors and within a narrow range of blood pressures, a high renin profile is clearly associated with an increased risk of myocardial infarction but not stroke (4).

Recently, two studies reported that the sulfhydryl-containing angiotensin-converting enzyme $(\mathrm{ACE})^{1}$ inhibitor captopril can reduce the progression of atherosclerosis: after 9 mo in Watanabe heritable hyperlipidemic rabbits (5) and after 6 mo in cholesterol-fed cynomolgus monkeys (6). These data suggest that the renin-angiotensin system (RAS) may play a direct role in plaque formation, possibly through angiotensin II stimulation of cell proliferation (7). However, although both of these studies used normotensive animals, captopril treatment also caused a significant reduction in blood pressure $(5,6)$. Such an effect could account for the reduction in atherosclerosis, since it has been shown that even in normotensive populations those with the lowest pressures are at a reduced risk for cardiovascular disease (8), while in cholesterol-fed animals, ligation of vessels to reduce pressure resulted in a significant reduction in lesion development $(9,10)$. In addition, captopril contains a sulfhydryl moiety that could act as an antioxidant $(5,6)$, inhibiting the formation of oxidation products that may be involved in atherogenesis $(11,12)$. It should also be noted that ACE inhibitors can affect other hormone systems, including enkephalins, substance $P$, kinins, and prostaglandins, which may also have effects on atherogenesis (13-16). Thus the mechanism for the effect of captopril on atherosclerosis remains unclear.

In an effort to differentiate among some of the possible mechanisms involved in the beneficial effects of ACE inhibition on atherogenesis, we have studied the effects of the converting enzyme inhibitor enalapril and the angiotensin II receptor antagonist, SC-51316, in a well-characterized model, the cholesterol-fed rabbit. This model has the advantage that both hypercholesterolemia and drug treatment can be initiated simultaneously, thus allowing one to evaluate drug effects during the early stages of lesion development. Enalapril is useful because it blocks the RAS by the same mechanism as captopril (17), although it lacks a sulfhydryl group and the associated antioxidant activity $(18,19)$. It has also been shown that in normotensive, cholesterol-fed rabbits enalapril has little or no effect on either blood pressure or lipid profiles (20). The compound SC-51316 has been shown to reversibly antagonize the $\mathrm{AT}_{1}$ receptor subtype in vivo (21), thus selectively blocking the RAS while having no known effects on other hormone systems.

1. Abbreviations used in this paper: ACE, angiotensin-converting enzyme; RAS, renin-angiotensin system. 


\section{Methods}

Protocol. In two separate experiments, groups of male, New Zealand white rabbits were placed on a standard diet $(100 \mathrm{~g} / \mathrm{d})$ supplemented with $0.3 \%$ cholesterol and $2 \%$ corn oil (Zeigler Brothers, Inc., Gardners, PA). Water was available ad lib. At the start of the diet half of the animals received either $10 \mathrm{mg} / \mathrm{kg}$ per $d$ enalapril or $30 \mathrm{mg} / \mathrm{kg}$ per d SC-51316, in a single oral dose. The remaining rabbits served as untreated controls. Groups of control and treated animals were killed after 1 and 3 mo of treatment. Tissues were removed for characterization of atherosclerotic lesions. Blood samples were taken for determination of plasma lipid concentrations and serum ACE activity. Mean arterial pressure was measured in conscious animals at the end of the study. Statistical differences between means were analyzed by $t$ test. Differences were considered significant at a value of $P<0.05$.

Plasma lipids and serum ACE activity. Plasma for lipid analysis was obtained by withdrawing blood from the ear vein into EDTA-containing tubes (Vacutainer; Becton Dickinson \& Co., Rutherford, NJ), followed by centrifugal separation of the cells. Total cholesterol was determined enzymatically, using the cholesterol oxidase reaction (22). HDL cholesterol was also measured enzymatically, after selective precipitation of LDL and VLDL by dextran sulfate with magnesium (23). Plasma triglyceride levels were determined by measuring the amount of glycerol released by lipoprotein lipase through an enzyme-linked assay (24). Serum ACE activity was determined spectrophotometrically, from hydrolysis of the synthetic tripeptide substrate $\mathrm{N}$-[3-[2furyl ] acryloyl]-L-phenyl-alanylglycylglycine (FAPGG) (25).

Blood pressure. On the day blood pressure was measured, animals were orally dosed in the morning as usual. Catheters for blood pressure and angiotensin peptide injection were then implanted in animals anesthetized with a ketamine/xylazine mixture. Measurements were begun after $4 \mathrm{~h}$ of recovery, $\sim 5 \mathrm{~h}$ after oral dosing. Resting mean arterial pressure was measured in conscious rabbits with a pressure transducer (Statham Instruments, Inc., Oxnard, CA ) connected to a catheter introduced through the right carotid artery and positioned into the ascending aorta. The pressor effects of angiotensin peptides were evaluated by continuous monitoring of blood pressure during intravenous bolus injections of peptide solutions via a catheter placed in the jugular vein. Multiple injections of peptides of increasing concentrations were made at intervals of 5-10 min after blood pressure had returned to baseline. The duration of drug effects on the pressor response to peptide injections was measured in conscious, catheterized animals at intervals ranging from 0.5 to $24 \mathrm{~h}$ after a single oral dose.

Atherosclerosis. Animals were killed by pentobarbital injection. Thoracic aortas were rapidly removed, immersion fixed in $10 \%$ neutral buffered Formalin, and stained with oil red $\mathrm{O}(0.3 \%)$. After a single longitudinal incision along the wall opposite the arterial ostia, the vessels were pinned open for evaluation of the plaque area. The percent plaque coverage was determined from the values for the total area examined and the stained area, by threshold analysis using a true color image analyzer (Videometric 150; American Innovision, Inc., San Diego, CA ) interfaced to a color camera (Toshiba 3CCD) mounted on a dissecting microscope. Tissue cholesterol was measured enzymatically as described, after extraction with a chloroform/methanol mixture (2:1) according to the method of Folch et al. (26).

In vitro vascular response. The abdominal aortas were rapidly excised, after injection of sodium pentobarbital, and placed in oxygenated Krebs-bicarbonate buffer. After removal of perivascular tissue, 3-mm ring segments were cut, placed in a $37^{\circ} \mathrm{C}$ muscle bath containing Krebs-bicarbonate solution, and suspended between two stainless steel wires, one of which was attached to a force transducer (Grass Instrument Co., Quincy, MA). Force changes in response to angiotensin II added to the bath were recorded on a chart recorder (model 8, Grass Instrument Co.).

\section{Results}

Converting enzyme inhibitor studies. RAS activity in enalapriltreated rabbits was, as expected, significantly blocked. After 3 mo of treatment, the blood pressure response to bolus injections of angiotensin I was markedly inhibited in the enalapriltreated rabbits at peptide concentrations ranging from 10 to $300 \mathrm{ng} / \mathrm{kg}$ (Fig. 1). Similarly, the serum ACE activity for treated animals was $<8 \%$ of the control values at both 1 and 3 mo (Table I). However, mean arterial pressure after 3 mo of treatment was not significantly affected, as shown in Table I.

RAS blockade with enalapril did not affect plasma lipid levels in cholesterol-fed rabbits. As shown in Table II, there were no significant differences between groups for total plasma cholesterol, HDL cholesterol, or plasma triglyceride concentrations after either 1 or 3 mo of treatment.

After 1 mo on the cholesterol diet, the mean value for the percent aortic plaque area was considerably less for the enalapril-treated animals $(2.3 \pm 0.8 \%)$ than for the controls $(16.2 \pm 6.9 \%)$ but, because of the variance in the control group, this difference was not statistically significant $(P=0.07$; Fig. 2 $A)$. There was, however, a small but significant difference in the tissue cholesterol concentration after 1 mo. As shown in Fig. $2 B$, vessels from treated animals contained $0.7 \pm 0.1 \mathrm{mg} / \mathrm{g}$ tissue, while vessels from control animals had a cholesterol concentration of $1.3 \pm 0.2 \mathrm{mg} / \mathrm{g}$ tissue $(P<0.05)$.

At $3 \mathrm{mo}$, vessels from the two groups showed an even greater difference in the development of atherosclerotic lesions, with the percent of lipid stained plaque area being $31.1 \pm 8 \%$ for the treated animals and $86.8 \pm 3.5 \%$ for the controls $(P<0.001)$ (Fig. $3 \mathrm{~A}$ ). Aortic cholesterol content was similarly affected by enalapril at $3 \mathrm{mo}$, with tissues from the treated group having a mean value of $7.4 \pm 1.8 \mathrm{mg} / \mathrm{g}$, while the control group had a value of $31.4 \pm 3.2 \mathrm{mg} / \mathrm{g}(P<0.001$; Fig. $3 \mathrm{~B})$.

Receptor antagonist studies. Preliminary dose-response studies were performed on rabbits to determine a dose of SC51316 that would be equivalent to enalapril at blocking the RAS. It was found that SC-51316, at a dose of $30 \mathrm{mg} / \mathrm{kg}$, displayed the same oral potency and duration of action as enalapril at $10 \mathrm{mg} / \mathrm{kg}$ (Fig. 4).

Treatment of cholesterol-fed rabbits with SC-51316 at 30 $\mathrm{mg} / \mathrm{kg}$ per $\mathrm{d}$ was found to have no significant effect on body weight, mean arterial pressure, or plasma lipid levels during the course of this study (see Tables III and IV).

Blockade of the RAS after 3 mo was similar to that seen for enalapril, with the pressor response to bolus injections of angiotensin II being significantly inhibited in treated animals (Fig.

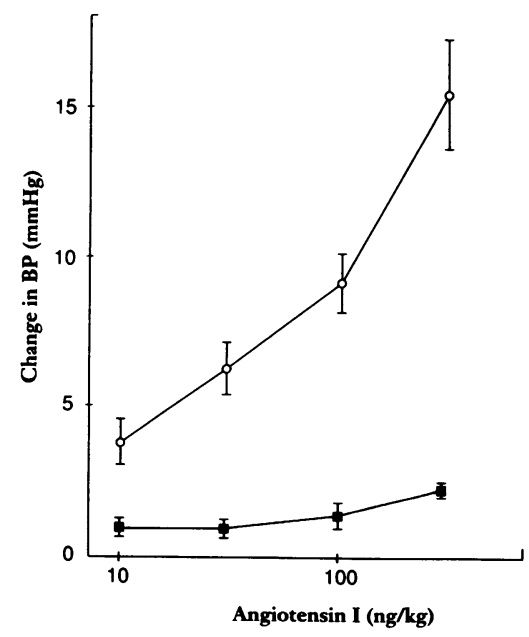

Figure 1. Blood pressure response to intravenous injection of angiotensin I in cholesterol-fed rabbits, after 3 mo of treatment. Controls $(n=6)$ : circles; enalapril treated $(n=8)$ : squares. Values are means \pm SEM. Differences between control and treated groups were significant $(P$ $<0.05)$ at all peptide concentrations tested. 
Table I. Effect of Enalapril on ACE Activity, Blood Pressure, and Body Weight in Cholsterol-fed Rabbits

\begin{tabular}{|c|c|c|c|c|}
\hline & \multicolumn{2}{|c|}{$1 \mathrm{mo}$} & \multicolumn{2}{|c|}{$3 \mathrm{mo}$} \\
\hline & Control & Treated & Control & Treated \\
\hline $\begin{array}{l}\text { Serum ACE } \\
\text { activity (U/liter) }\end{array}$ & $97 \pm 9$ & $7 \pm 1^{*}$ & $96 \pm 8$ & $5 \pm 1$ \\
\hline $\begin{array}{l}\text { Mean arterial } \\
\text { pressure }(\mathrm{mmHg})\end{array}$ & ND & ND & $79 \pm 3$ & $81 \pm 2$ \\
\hline $\begin{array}{l}\text { Body } \\
\text { weight }(\mathrm{kg})\end{array}$ & $3.2 \pm .1$ & $3.0 \pm .1$ & $3.5 \pm .1$ & $3.5 \pm .1$ \\
\hline
\end{tabular}

Values are means \pm SEM. $n=10$ except for control $(n=6)$ and treated $(n=8)$ for mean arterial pressure. ${ }^{*} P<0.001$ vs. control. ND, not determined.

5). The vasoconstrictor response to angiotensin II in vitro was also reduced in aortic ring segments from the SC-51316 treated group, shown in Fig. 6. Treatment with the receptor blocker for 3 mo shifted the $\mathrm{EC}_{50}$ from $3.8 \pm 0.6$ to $38 \pm 12 \mathrm{nM}(P<0.05, n$ $=7$ ), while the calculated pD2 was reduced from $8.46 \pm 0.08$ to $7.54 \pm 0.13(P<0.01, n=7)$.

After 1 mo on the cholesterol diet, the mean value for the percent aortic plaque area was less for the treated animals

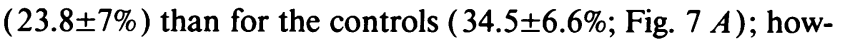
ever, this difference was not statistically significant $(P=0.27)$. Similarly, after 1 mo there was no significant difference between the two groups in the amount of tissue cholesterol extracted from the vessels, with control values having a mean of $1.6 \pm 0.5 \mathrm{mg} / \mathrm{g}$, while treated animals had a mean value of $0.8 \pm 0.2 \mathrm{mg} / \mathrm{g}(P=0.13$; Fig. $7 \mathrm{~B})$.

At $3 \mathrm{mo}$, vessels from the two groups also showed no significant difference in the development of atherosclerotic lesions, with the percent of lipid stained plaque area being $75.3 \pm 7.5 \%$ for the controls and $66.4 \pm 6.7 \%$ for the treated animals $(P$ $=0.39$; Fig. $8 \mathrm{~A}$ ). Aortic cholesterol content was also not significantly affected by SC-51316 treatment after $3 \mathrm{mo}$, with control animal tissues having a mean value of $25.1 \pm 3.3 \mathrm{mg} / \mathrm{g}$ and the treated group having a value of $18.9 \pm 3.6 \mathrm{mg} / \mathrm{g}(P=0.22$; Fig. $8 B$ ).

\section{Discussion}

Numerous factors have been implicated in the initiation and development of atherosclerotic plaques, including hyperten-

Table II. Effect of Enalapril on Plasma Lipids in Cholesterol-fed Rabbits

\begin{tabular}{|c|c|c|c|c|}
\hline & \multicolumn{2}{|c|}{$1 \mathrm{mo}$} & \multicolumn{2}{|c|}{$3 \mathrm{mo}$} \\
\hline & Control & Treated & Control & Treated \\
\hline $\begin{array}{l}\text { Total } \\
\text { cholesterol }\end{array}$ & $1,268 \pm 197$ & $1,065 \pm 95$ & $1,404 \pm 119$ & $1,210 \pm 126$ \\
\hline $\begin{array}{l}\text { HDL } \\
\text { cholesterol } \\
\text { Triglycerides }\end{array}$ & $\begin{array}{c}49 \pm 8 \\
144 \pm 27\end{array}$ & $\begin{array}{r}50 \pm 7 \\
119 \pm 8\end{array}$ & $\begin{array}{c}33 \pm 4 \\
194 \pm 21\end{array}$ & $\begin{array}{c}30 \pm 4 \\
145 \pm 16\end{array}$ \\
\hline
\end{tabular}

Values are means \pm SEM, measured in $\mathrm{mg} / \mathrm{dl} . n=10$.
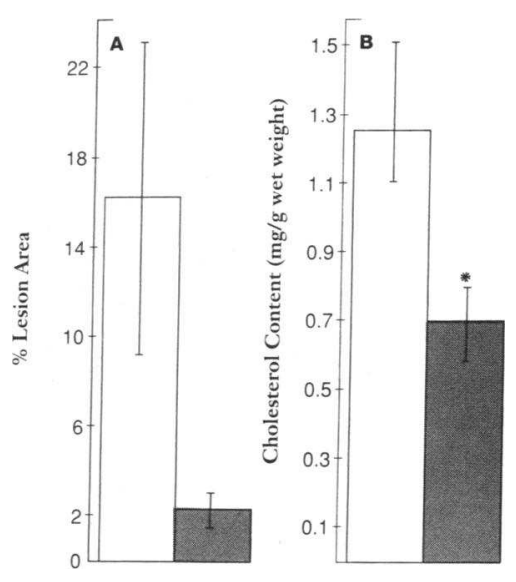

Figure 2. Effect of enalapril on aortic atherosclerosis after $1 \mathrm{mo} .(A)$ percent lipid-stained area. $(B)$ tissue cholesterol content. Controls $(n=10)$ : open bars; enalapril treated $(n$ $=10$ ): shaded bars. Values are means \pm SEM. ${ }^{*} P$ $<0.05$.

sion, high plasma cholesterol levels, lipoprotein oxidation, and cellular chemotactic and growth factors. Therapies that attenuate atherogenesis usually do so by affecting one or more of these factors. In previously published studies demonstrating reduced plaque formation with captopril therapy, the treated groups also had blood pressure values lower than the controls $(5,6)$. Since hypotension, in both humans $(8)$ and experimental animals $(9,10)$, is associated with decreased atheroma formation, the effects of captopril on blood pressure in these studies could explain the observed reduction in vascular lesions. However, the results reported here show that enalapril treatment, while also significantly attenuating plaque formation, had no effect on conscious blood pressure, thus ruling out hypotension as a possible mechanism for the observed effects of ACE inhibition in this study. In other studies in which antihypertensive drugs have an effect on atherosclerosis, there may also be an effect on lipid metabolism (27). However, the results reported here (Table II) and by others (28) indicate that ACE inhibitors have no effect on plasma lipid levels. Thus, our results cannot be explained by effects on either blood pressure or plasma lipid levels.

Alternatively, it is possible that the effects of captopril on atherosclerosis may be related to its antioxidant properties. Thus, it has been suggested that the oxidation of LDL might be inhibited due to captopril's sulfhydryl group, $(5,6)$, possibly reducing the formation of vascular lesions (29). A similar mechanism has been suggested for the effects of probucol and its analogues ( 30 ) and the antioxidant butylated hydroxytolu-
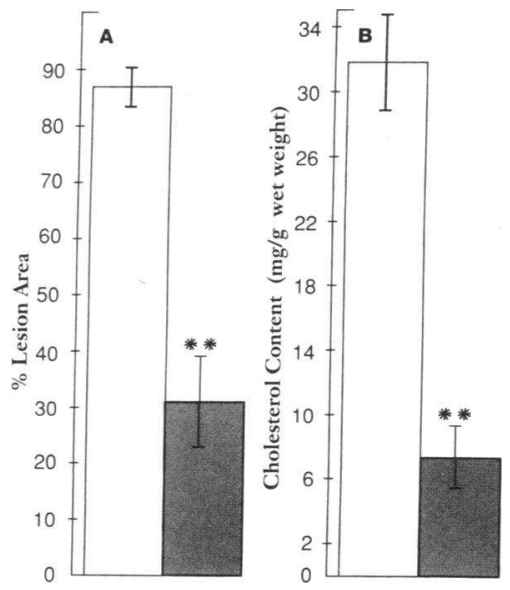

Figure 3. Effect of enalapril on aortic atherosclerosis after $3 \mathrm{mo} .(A)$ percent lipid-stained area. $(B)$ tissue cholesterol content. Controls $(n=10)$ : open bars; enalapril treated $(n$ $=10)$ : shaded bars. Values are means \pm SEM. ${ }^{* *} P$ $<0.001$. 


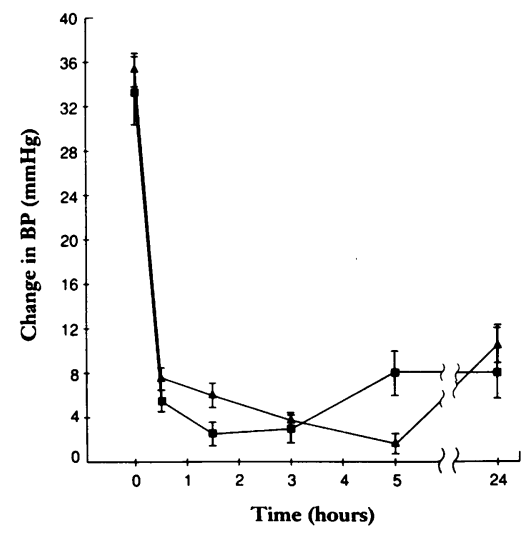

administered at $0 \mathrm{~h}$. Duration of drug effect 0.5 to $24 \mathrm{~h}$. Values are means \pm SEM.

ene (31). However, the data presented here show reduced lesions in animals treated with enalapril, which, unlike captopril, is not capable of inhibiting free radical-induced lipid peroxidation (18) or scavenging oxygen-derived free radicals (19), thus indicating that antioxidant activity is not necessary for ACE inhibitors to reduce plaque formation. Similarly, other sulfhydryl-related effects of captopril, such as those observed in cultured endothelial cells (32), also do not necessarily play a role in the attenuation of atherogenesis by converting enzyme inhibitors.

In an earlier report, no significant effect on atherosclerosis was seen with enalapril treatment of cholesterol-fed rabbits (20). However, the dose administered was only $0.075-0.1 \mathrm{mg} /$ $\mathrm{kg}$ per d, compared with our treatment protocol with a dose of $10 \mathrm{mg} / \mathrm{kg}$ per $\mathrm{d}$. The lower dose used in the earlier study appears to be the most likely reason for the observed lack of effect on atherosclerosis.

The importance of cell migration and proliferation in plaque formation is well established (33). In previous reports showing the efficacy of captopril in reducing atherosclerosis $(5$, 6 ), it was noted that this effect could result from the decrease in angiotensin II levels caused by ACE inhibition, since it has been observed that angiotensin II can be mitogenic in cultured cells (34) and that it can stimulate the synthesis of growth and chemotactic factors $(35,36)$. However, the results reported here indicate that blockade of the RAS by the angiotensin II receptor antagonist SC-51316 does not significantly inhibit

Table III. Effect of SC-51316 on Body Weight and Blood Pressure

\begin{tabular}{lccccc}
\hline & \multicolumn{2}{c}{$1 \mathrm{mo}$} & & \multicolumn{2}{c}{3 mo } \\
\cline { 2 - 3 } \cline { 5 - 6 } & Control & Treated & & Control & Treated \\
\hline $\begin{array}{l}\text { Body } \\
\quad \text { weight (kg) }\end{array}$ & $3.0 \pm .1$ & $2.9 \pm .1$ & & $3.4 \pm .1$ & $3.5 \pm .1$ \\
$n$ & 13 & 10 & & 10 & 10 \\
$\begin{array}{l}\text { Mean arterial } \\
\text { pressure (mmHg) }\end{array}$ & ND & ND & & $81 \pm 5$ & $79 \pm 5$ \\
$n$ & & & 5 & 5 \\
\hline
\end{tabular}

Values are means \pm SEM.
Table IV. Effect of SC-51316 on Plasma Lipids in Cholesterol-fed Rabbits

\begin{tabular}{lccccc}
\hline & \multicolumn{2}{c}{1 mo } & & \multicolumn{2}{c}{3 mo } \\
\cline { 2 - 3 } \cline { 5 - 6 } \cline { 5 - 6 } & Control & Treated & & Control & Treated \\
\hline $\begin{array}{l}\text { Total } \\
\text { cholesterol }\end{array}$ & $1,425 \pm 101$ & $1,518 \pm 118$ & $1,560 \pm 180$ & $1,330 \pm 110$ \\
$n$ & 13 & 10 & & 5 & 5 \\
HDL & & & & \\
$\quad$ cholesterol & $51 \pm 4$ & $47 \pm 5$ & & $41 \pm 2$ & $36 \pm 9$ \\
$n$ & 13 & 10 & & 5 & 5 \\
Triglycerides & $158 \pm 20$ & $153 \pm 27$ & & $169 \pm 24$ & $114 \pm 13$ \\
$n$ & 12 & 10 & & 5 & 5 \\
& & & &
\end{tabular}

Values are means \pm SEM, in $\mathrm{mg} / \mathrm{dl}$.

plaque formation, in marked contrast to the results with the ACE inhibitor enalapril. After 3 mo the difference between the aortic plaque area in the enalapril treated group and the controls was $55.7 \%$. However, in the same 3 -mo period, the difference between the SC-51316-treated animals and the controls was only $8.9 \%$. Statistical analysis indicates that the enalapril effect was highly significant $(P<0.001)$ with a sample size of 10 . However, if the $8.9 \%$ difference seen with SC-51316 treatment were true, a fivefold increase in sample size would be required to reach significance at the 0.05 level. Thus it appears that enalapril's effect on the RAS contributes little, if anything, to the drug's effect on atherosclerosis.

Another possible explanation for the difference between enalapril and the receptor antagonist is that SC-51316 lacks the potency or duration to block the RAS sufficiently to attenuate atherogenesis. However, at the doses used, both drugs were equally effective in blocking equivalent pressor responses to angiotensin I or II for $24 \mathrm{~h}$ (Fig. 4). It was also observed that there was no decline in the receptor-blocking effect of SC51316 after chronic dosing in cholesterol-fed animals (Fig. 5). Thus, there was no apparent increase in tolerance or metabolism of SC-51316, which might reduce its efficacy in blocking the RAS. In addition, it was found that chronic treatment with SC-51316 results in the functional down-regulation of vascular

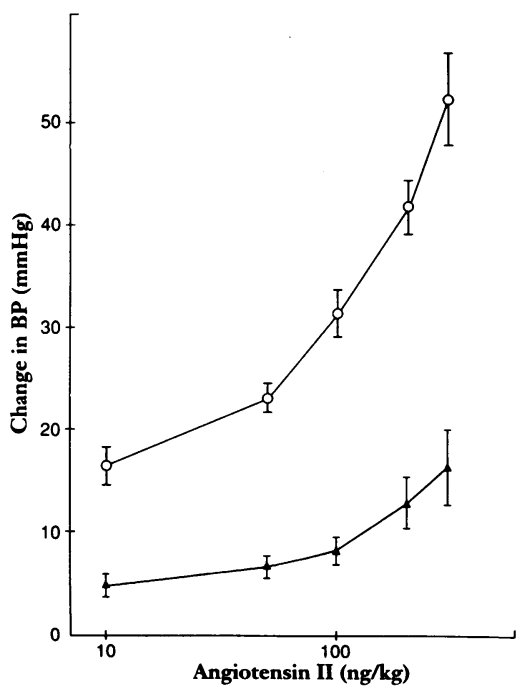

Figure 5. Blood pressure response to intravenous injection of angiotensin II in cholesterol-fed rabbits, after 3 mo of treatment with SC-51316. Controls $(n=5)$ : circles; SC-51316 treated $(n=5)$ : triangles. Values are means \pm SEM. Differences between control and treated groups were significant $(P<0.05)$ at all peptide concentrations tested. 


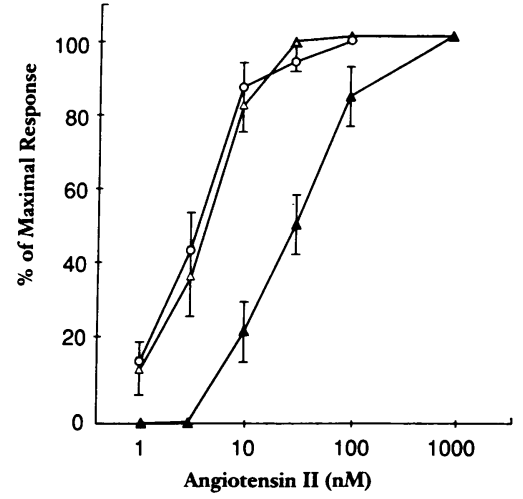

Figure 6. Contraction responses of aortic rings to angiotensin II. Tissue isolated from untreated cholesterol-fed rabbits $(n=7)$ (circles), cholesterol-fed rabbits, treated with SC-51316 $(n=7)$ (filled triangles) and chow-fed, untreated rabbits $(n=4)$ (open triangles). Values are means \pm SEM. angiotensin II receptors, indicating a second mechanism by which this drug can further block the vascular RAS in vivo (Fig. 6). This down-regulation presumably occurs in response to high circulating levels of angiotensin II (37), caused by blockade of angiotensin receptors controlling feedback inhibition of renin release $(38)$.

Since ACE inhibitors block the formation of angiotensin II, all angiotensin II receptor subtypes are functionally blocked. However, SC-51316 is a specific antagonist for the $\mathrm{AT}_{1}$ receptor subtype (21). Thus, if angiotensin II stimulates atherogenesis via a different receptor (e.g., $\mathrm{AT}_{2}$ ), then $\mathrm{ACE}$ inhibitors, but not $\mathrm{AT}_{1}$ antagonists, will attenuate lesion development. Although this possibility is consistent with the results described here, it appears to be unlikely in view of current reports indicating that vascular tissue contains only $\mathrm{AT}_{1}$ receptors (39).

A more likely explanation for these results is that other peptide hormones, also regulated by ACE, may play a role in suppressing the development of atherosclerosis. For example, the activity of the vasoactive hormone bradykinin is potentiated in the presence of ACE inhibitors (40). Increased bradykinin activity can stimulate endothelial cell production of prostacyclin or endothelium-derived relaxing factor/nitric oxide (41), which could inhibit platelet activation $(42,43)$ and monocyte adhesion or chemotaxis (44) at plaque sites, potentially attenuating lesion formation $(45,46)$. Consistent with this mechanism is the report that in vivo platelet activity is significantly reduced in hypertensive patients receiving $\mathrm{ACE}$ inhibitors but not other standard antihypertensive therapies (47). A role for kinins in mediating the effect of ACE inhibitors on vascular lesions is also supported by the report that a brady-
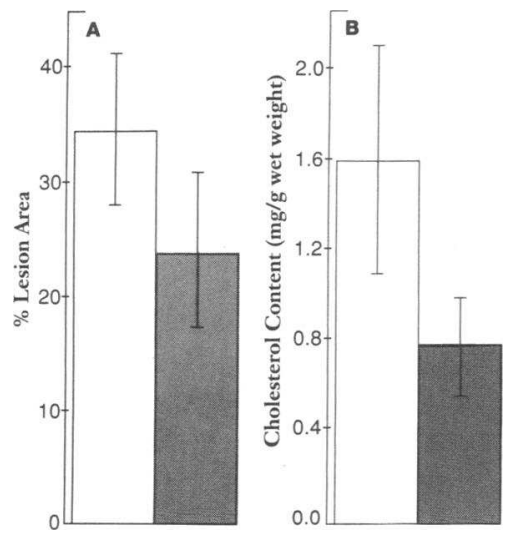

Figure 7. Effect of SC51316 on aortic atherosclerosis after 1 mo. $(A)$ percent lipid-stained area. $(B)$ tissue cholesterol content. Controls $(n=13)$ : open bars; SC-51316 treated $(n$ $=10$ ): shaded bars. Values are means \pm SEM. Differences are not statistically significant.
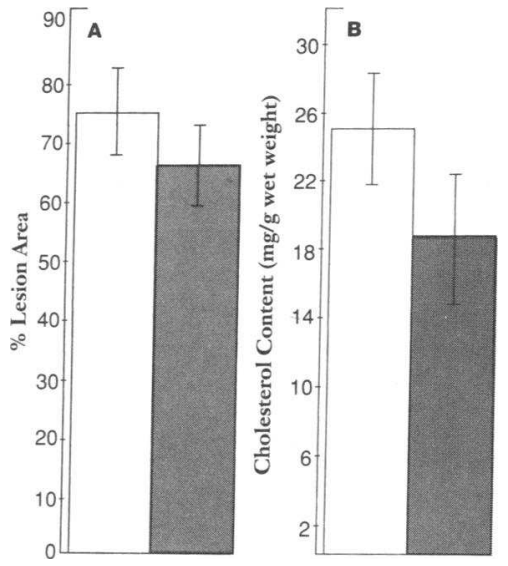

Figure 8. Effect of SC51316 on aortic atherosclerosis after $3 \mathrm{mo}$. $(A)$ percent lipid-stained area. $(B)$ tissue cholesterol content. Controls $(n=10)$ : open bars; SC-51316 treated $(n$ $=10$ ): shaded bars.

Values are means \pm SEM. Differences are not statistically significant.

kinin receptor antagonist (HOE 140) can suppress the attenuation of vascular lesions by ramipril, after arterial injury in rats by balloon angioplasty ( 48 ).

Such speculations notwithstanding, it does not appear that a reduction in angiotensin II can be the primary mechanism by which ACE inhibitors attenuate atherogenesis. Instead it is suggested that other peptide hormones may be important. Thus, in the absence of effects on systemic blood pressure or changes in plasma lipids, it appears that an ACE-dependent factor can reduce the progression of atherosclerosis, probably by modulating the effects that high plasma cholesterol levels have on cellular elements involved in the early stages of plaque formation. Further characterization of this mechanism may provide new leads in the development of unique therapies for treating atherosclerosis and its clinical sequelae.

\section{Acknowledgments}

We thank M. K. Baldwin, D. Harah, and G. Moore for their excellent technical assistance; Dr. J. Sebaugh for help in data analysis; and L. Lee for assisting with the preparation of the manuscript.

\section{References}

1. MacMahon, S. W., J. A. Cutler, C. D. Furberg, and G. H. Payne. 1986. The effects of drug treatment for hypertension on morbidity and mortality from cardiovascular disease: a review of randomized trials. Prog. Cardiovasc. Dis. 29(Suppl. 1):99-118.

2. Holme, I. 1988. Drug treatment of mild hypertension to reduce the risk of CHD: is it worthwhile? Stat. Med. 7:1109-1120.

3. McGill, H. C., Jr. 1984. Persistent problems in the pathogenesis of atherosclerosis. Arteriosclerosis. 4:443-451.

4. Alderman, M. H., S. Madhavan, W. L. Ooi, H. Cohen, J. E. Sealey, and J. H. Laragh. 1991. Association of the renin-sodium profile with the risk of myocardial infarction in patients with hypertension. N. Engl. J. Med. 324:1098-1 104

5. Chobanian, A. V., C. C. Haudenschild, C. Nickerson, and R. Drago. 1990. Antiatherogenic effect of captopril in the Watanabe heritable hyperlipidemic rabbit. Hypertension. 15:327-331.

6. Aberg, G., and P. Ferrer. 1990. Effects of captopril on atherosclerosis in cynomolgus monkeys. J. Cardiovasc. Pharmacol. 15(Suppl. 5):S65-S72.

7. Daemen, M. J. A. P., D. M. Lombardi, F. T. Bosman, and S. M. Schwartz. 1991. Angiotensin II induces smooth muscle cell proliferation in the normal and injured rat arterial wall. Circ. Res. 68:450-456.

8. Castelli, W. P. 1984. Epidemiology of coronary heart disease: the Framingham study. Am. J. Med. 76(Suppl. 2A):4-12.

9. Bomberger, R. A., C. K. Zarins, K. E. Taylor, and S. Glagov. 1980. Effect of hypotension on atherogenesis and aortic wall composition. J. Surg. Res. 28:402409.

10. Lopez, J. A. G., M. L. Armstrong, D. G. Harrison, D. J. Piegors, and D. D. Heistad. 1988. Responsiveness of iliac collateral vessels to constrictor stimuli in atherosclerotic primates. Circ. Res. 63:1020-1028. 
11. Quinn, M. T., S. Parthasarathy, L. G. Fong, and D. Steinberg. 1987. Oxidatively modified low density lipoproteins: a potential role in recruitment and retention of monocyte/macrophages during atherogenesis. Proc. Natl. Acad. Sci. USA. 84:2995-2998.

12. Heinecke, J. W. 1987. Free radical modification of low-density lipoprotein: mechanisms and biological consequences. Free Radical Biol. Med. 3:65-73.

13. Ujhelyi, M. R., R. K. Ferguson, and P. H. Vlasses. 1989. Angiotensin converting enzyme inhibitors: mechanistic controversies. Pharmacotherapy. 9:351-362.

14. Schror, K. 1990. Converting enzyme inhibitors and the interaction between kinins and eicosanoids. J. Cardiovasc. Pharmacol. 15(Suppl. 6):S60-S68

15. Swartz, S. L. 1987. The role of prostaglandins in mediating the effects of angiotensin converting enzyme inhibitors and other antihypertensive drugs. Cardiovasc. Drugs Ther. 1:39-43.

16. Schror, K. 1987. Eicosanoids and atherosclerosis. In Carotid Artery Plaques. M. Hennerici, editor. Karger, Basel. 37-46.

17. Bauer, J. H. 1990. Angiotensin converting enzyme inhibitors. Am. J. Hypertens. 3:331-337.

18. Mak, I. T., M. A. Freedman, B. F. Dickens, and W. B. Weglicki. 1990. Protective effects of sulfhydryl-containing angiotensin converting enzyme inhibitors against free radical injury in endothelial cells. Biochem. Pharmacol. 40:2169-2175.

19. Westlin, W., and K. M. Mullane. 1988. Does captopril attenuate reperfusion-induced myocardial dysfunction by scavenging free radicals? Circulation. 77(Suppl. 1):I-30-I-39.

20. Overturf, M., H. Sybers, J. Schaper, and H. Taegtmeyer. 1986. Hypertension and atherosclerosis in cholesterol fed rabbits. Atherosclerosis. 59:283-299.

21. Olins, G. M., V. M. Corpus, E. G. McMahon, M. A. Palomo, J. R. Schuh, D. J. Blehm, H.-C. Huang, D. B. Reitz, R. E. Manning, and E. H. Blaine. 1992. In vitro pharmacology of a nonpeptide angiotensin II receptor antagonist, SC51316. J. Pharm. Exp. Ther. 261:1037-1043.

22. Allain, C. A., L. S. Poon, C. S. G. Chan, W. Richmond, and P. C. Fu. 1974. Enzymatic determination of total serum cholesterol. Clin. Chem. 20:470 475.

23. Warnick, G. R., J. Benderson, and J. J. Albers. 1982. Dextran sulfate-Mg precipitation procedure for quantitation of high density lipoprotein cholesterol. Clin. Chem. 28:1379-1388.

24. Bucolo, G., and H. David. 1973. Quantitative determination of serum triglycerides by the use of enzymes. Clin. Chem. 19:476-482.

25. Holmquist, B., P. Bunning, and J. F. Riordan. 1979. A continuous spectrophotometric assay for angiotensin converting enzyme. Anal. Biochem. 95:540548.

26. Folch, J., M. Lees, and G. H. S. Stanley. 1957. A simple method for the isolation and purification of total lipids from animal tissues. J. Biol. Chem 226:497-509.

27. Lardinois, C. K., and S. L. Neuman. 1988. The effects of antihypertensive agents on serum lipids and lipoproteins. Arch. Intern. Med. 148:1280-1288.

28. Weidmann, P., D. E. Uehlinger, and A. Gerber. 1985. Antihypertension treatment and serum lipoproteins. J. Hypertens. 3:297-306.

29. Steinberg, D., S. Parthasarathy, T. E. Carew, J. C. Khoo, and J. L. Witztum. 1989. Beyond cholesterol: modifications of low-density lipoprotein that increase its atherogenicity. $N$. Engl. J. Med. 320:915-924.

30. Mao, S. J. T., M. T. Yates, R. A. Parker, E. M. Chi, and R. L. Jackson. 1991. Attenuation of atherosclerosis in a modified strain of hypercholesterolemic Watanabe rabbits with use of a probucol analogue (MDL 29,311) that does not lower serum cholesterol. Arteriosclerosis and Thrombosis. 11:1266-1275.
31. Bjorkhem, I., A. Henrikkson-Freyschuss, O. Breuer, U. Diczfalusy, L. Berglund, and P. Henrikkson. 1991. The antioxidant butylated hydroxytoluene protects against atherosclerosis. Arteriosclerosis and Thrombosis. 11:15-22.

32. Nakagawa, M., K. Kobayashi, S. Sawada, T. Toyoda, K. Shirai, K. Katoh, K. Yamamoto, H. Tsuji, S. Sasaki, and K. Takeda. 1991. Comparative studies of angiotensin converting enzyme inhibitors with and without the SH-radical. $\mathrm{Am}$. J. Hypertens. 4(1, Pt. 2):54s-55s.

33. Ross, R. 1986. The pathogenesis of atherosclerosis-an update. N. Engl. J. Med. 314:488-450.

34. Geisterfer, A. A. T., M. J. Peach, and G. K. Owens. 1988. Angiotensin II induces hypertrophy, not hyperplasia, of cultured rat aortic smooth muscle cells. Circ. Res. 62:749-756.

35. Naftilan, A. J., R. E. Pratt, and V. J. Dzau. 1989. Induction of platelet-derived growth factor A-chain and c-myc gene expressions by angiotensin II in cultured rat vascular smooth muscle cells. J. Clin. Invest. 83:1419-1424.

36. Stouffer, G. A., and G. K. Owens. 1992. Angiotensin II-induced mitogenesis of SHR-derived cultured smooth muscle cells is dependent on autocrine production of TGF- $\beta$. Circ. Res. 70:820-828.

37. Platia, M. P., K. J. Catt, G. D. Hodgen, and G. Aguilera. 1986. Regulation of primate angiotensin II receptors during altered sodium intake. Hypertension. 8:1121-1126.

38. Keeton, T. K., and W. B. Campbell. 1981. The pharmacological alteration of renin release. Pharmacol. Rev. 31:81-227.

39. Wong, P. C., S. D. Hart, A. M. Zaspel, A. T. Chiu, R. J. Ardecky, R. D. Smith, and P. B. M. W. M. Timmermans. 1990. Functional studies of nonpeptide angiotensin II receptor subtype-specific ligands: DuP 753 (Ang II-1) and PD123177 (Ang II-2). J. Pharmacol. Exp. Ther. 255:584-592.

40. Nwator, I. A. A., and E. T. Whalley. 1989. Angiotensin converting enzyme inhibitors and expression of des-Arg ${ }^{9}$-BK ( $k$ inin $\mathrm{B}_{1}$ ) receptors in vivo. Eur. J. Pharmacol. 160:125-132.

41. Moncada, S., R. M. J. Palmer, and E. A. Higgs. 1991. Nitric oxide: physiology, pathophysiology and pharmacology. Pharmacol. Rev. 43:109-142.

42. Radomski, M. W., R. M. J. Palmer, and S. Moncada. 1987. Comparative pharmacology of endothelium-derived relaxing factor, nitric oxide and prostacyclin in platelets. Br. J. Pharmacol. 92:181-187.

43. Radomski, M. W., R. M. J. Palmer, and S. Moncada. 1987. The role of nitric oxide and cGMP in platelet adhesion to vascular endothelium. Biochem. Biophys. Res. Commun. 148:1482-1489.

44. Bath, P. M. W., D. G. Hassall, A.-M. Gladwin, R. M. J. Palmer, and J. F. Martin. 1991. Nitric oxide and prostacyclin: divergence of inhibitory effects on monocyte chemotaxis and adhesion to endothelium in vitro. Arteriosclerosis and Thrombosis. 11:254-260.

45. Fuster, V., D. N. Fass, and E. J. W. Bowie. 1979. Resistance to atherosclerosis in pigs with genetic and therapeutic inhibition of platelet function. Thromb. Haemostasis. 42:270-271.

46. Gerrity, R. G. 1981. The role of the monocyte in atherogenesis. I. Transition of blood-borne monocytes into foam cells in fatty lesions. Am. J. Pathol. 103:181-190.

47. Islim, I. F., D. G. Beevers, and D. Bareford. 1992. The effect of antihypertensive drugs on in vivo platelet activity in essential hypertension. J. Hypertens. 10:379-383.

48. Farhy, R. D., K.-L. Ho, O. A. Carretero, and A. G. Scicli. 1992. Kinins mediate the antiproliferative effect of ramipril in rat carotid artery. Biochem. Biophys. Res. Commun. 182:283-288. 